\title{
Przekroczenie granic obrony koniecznej - w sprawie propozycji nowelizacji art. 25 Kodeksu karnego ${ }^{1}$
}

Exceeding the boundaries of necessary defense - regarding the petition concerning amendment of Article 25 of the Criminal Code: The author of the petition postulates the introduction of Article 25 para. 3a of the Criminal Code, in which the privilege of impunity for a person crossing the borders of necessary defense in a situation of defense against an unlawful, direct assault directed at legal rights set out in that regulation, would be guaranteed. It is concluded in the opinion that a more appropriate solution would be to link the non-subject to punishment of persons crossing the boundaries of the necessary defense with a more universal and capacious formula of "justifying the crossing of the limits of necessary defense by the circumstances accompanying the attack."Thus the petition does not seem to be justified. The mere fact that a person crossing the boundaries of defense necessary would not be subject of the penalty only due to the fact that he/she acts in defense of certain legal rights, made in isolation from other important elements of the incident, reduces the assessment of his/her behavior and may lead to mandatory release from penalties in socially unacceptable cases.

Keywords: Criminal Code | petition | necessary defense

Słowa kluczowe: Kodeks karny | petycja | obrona konieczna

Asystent w Instytucie Wymiaru Sprawiedliwości, ekspert ds. legislacji BAS; pawel.bachmat@sejm.gov.pl.

\section{Treść i cel petycji}

Przedmiotem petycji jest żądanie podjęcia inicjatywy ustawodawczej w zakresie nowelizacji art. $25 \$ 1-3$ ustawy z 6 czerwca 1997 r. - Kodeks karny (t.j. Dz.U. 2016, poz. 1137, ze zm.; dalej: k.k. lub Kodeks karny), w którym ustawodawca określił granice oraz prawne konsekwencje działania w ramach obrony koniecznej, jak również z przekroczeniem granic tego kontratypu. Stosownie do obowiązującego brzmienia art. 25 k.k.: $\$ 1$. Nie popetnia przestępstwa, kto w obronie koniecznej

1 Opinia w sprawie nowelizacji art. 25 Kodeksu karnego (przekroczenie granic obrony koniecznej) sporządzona 19 września 2017 r. na zlecenie przewodniczącego Komisji ds. Petycji; BAS-WAP 871/17. 
odpiera bezpośredni, bezprawny zamach na jakiekolwiek dobro chronione prawem. $\$ 2$. W razie przekroczenia granic obrony koniecznej, w szczególności gdy sprawca zastosowat sposób obrony niewspótmierny do niebezpieczeństwa zamachu, sąd może zastosować nadzwyczajne złagodzenie kary, a nawet odstąić od jej wymierzenia. \$3. Nie podlega karze, kto przekracza granice obrony koniecznej pod wplywem strachu lub wzburzenia usprawiedliwionych okolicznościami zamachu.

Autor petycji postuluje wprowadzenie dodatkowego przepisu art. $25 \$ 3$ a k.k., w którym zagwarantowany zostałby przywilej bezkarności osoby przekraczającej granice obrony koniecznej w sytuacji obrony przed bezprawnym, bezpośrednim zamachem skierowanym na wymienione $\mathrm{w}$ tym uregulowaniu dobra prawne człowieka. Artykuł $25 \$ 3$ a k.k. w zaproponowanym brzmieniu przybrałby następującą postać redakcyjną: Nie podlega karze ten, kto przekracza granice obrony koniecznej, jeżeli dobrem zagrożonym zamachem jest bezpieczeństwo powszechne, $\dot{z} y c i e$, zdrowie, wolność, wolność seksualna, lub mienie, gdy zamach na mienie połączony jest $z$ użyciem przemocy lub wdarciem się do cudzego domu, mieszkania, lokalu, pomieszczenia lub ogrodzonego terenu.

W uzasadnieniu wskazano m.in., że celem nowelizacji jest przesunięcie akcentu ze sfery emocjonalnej osoby odpierającej zamach na zobiektywizowany przedmiot zamachu. W przypadku zaproponowanej zmiany przełożyć się to ma na uwolnienie organów ścigania od konieczności ustalania stanu emocjonalnego osoby odpierającej zamach na gruncie niedookreślonych pojęć strachu i wzburzenia. Wedle przekonania wyrażonego przez autora petycji organy prowadzące postępowanie będą mogły wziąć pod uwagę jedynie fakt, czy zamach był bezprawny i czy godził $\mathrm{w}$ wyliczone w postulowanym art. $25 \$ 3 \mathrm{a}$ k.k. dobra prawne, a przy zamachu na mienie także, czy atak nastąpił w sposób i miejscu określonym $w$ tym przepisie.

Nowelizacja ma służyć osiągnięciu prewencji ogólnej. W ocenie składającego petycję jest ukierunkowana na osiągnięcie stanu, w którym napastnik będzie zmuszony liczyć się z prawem każdego obywatela do powstrzymania zamachu bez względu na wystąpienie strachu lub wzburzenia usprawiedliwionego okolicznościami zamachu. W następstwie zachęci to obywateli do przeciwdziałania aktom przemocy ze strony napastników - bez obawy przed poniesieniem z tego tytułu odpowiedzialności karnej.

\section{Czy petycja mieści się w zakresie zadań i kompetencji adresata petycji (art. 2 ust. 3 ustawy o petycjach)?}

Petycja dotyczy zmiany ustawy przez Sejm. Zgodnie z art. 95 ust. 1 Konstytucji RP władzę ustawodawczą w Rzeczypospolitej Polskiej sprawują Sejm i Senat. Natomiast stosownie do art. 118 ust. 1 Konstytucji RP inicjatywa ustawodawcza przysługuje m.in. posłom. Artykuł 32 ust. 2 regulaminu Sejmu, w związku 
Z art. 112 Konstytucji RP, precyzuje, że poselskie projekty ustaw mogą być wnoszone przez komisje sejmowe lub grupę co najmniej 15 posłów podpisujących projekt.

Uwzględniając powyższe, należy uznać, że petycja mieści się w zakresie zadań i kompetencji Sejmu.

\section{Wymogi formalne (art. 4 ust. 1 i 2 oraz ustawy o petycjach)}

Złożona petycja spełnia wymogi formalne określone w art. 4 ust. 1 i 2 ustawy z 11 lipca 2014 r. o petycjach (t.j. Dz.U. 2017, poz. 1123) - zawiera oznaczenie podmiotu wnoszącego petycję, wskazuje jego miejsce zamieszkania, adresata petycji oraz jej przedmiot.

\section{Kwestie, które ekspert uznaje za istotne w związku z petycją}

\section{Podstawowe informacje na temat instytucji obrony koniecznej}

Instytucja obrony koniecznej ma na celu nie tylko ochronę dobra bezprawnie i bezpośrednio zaatakowanego, ale również kształtowanie zasady, że prawo nie powinno ustępować przed bezprawiem ${ }^{2}$. Ten trafny pogląd Sądu Najwyższego, choć wyrażony na gruncie kodyfikacji karnej z 1969 r., zachowuje w pełni aktualność pod rządami obowiązującego Kodeksu karnego.

Obrona konieczna jest instytucją mającą ugruntowaną tradycję w polskim systemie prawa. Jako okoliczność wyłączającą bezprawność czynu zabronionego, a co za tym idzie jego przestępność, znały ją poprzednie kodyfikacje karne z lat $1932^{3}$ i $1969^{4}$. Zasadność jej obowiązywania nie budziła wątpliwości. Do tej tradycji nawiązał ustawodawca, wprowadzając obronę konieczną do obowiązującego Kodeksu karnego. Jest ona także uregulowana w Kodeksie cywilnym (art. 343 $\$ 1$, art. 423) $)^{5}$.

W prawie karnym przyjmuje się, że obrona konieczna należy do kategorii tzw. kontratypów. Według twórcy pojęcia kontratypu W. Woltera: [p]rzez kontratypy rozumiemy te i tylko te okoliczności, które, mimo że czyn wykazuje ustawowe znamiona czynu zabronionego przez ustawę pod groźba kary, jednak powoduja, że nie jest społecznie szkodliwy (ew. jest dodatni), a tym samym bezprawny; sa to więc oko-

2 Wyrok SN z 27 lipca 1973 r., sygn. akt IV KR 153/73, OSNKW 1974, nr 1, poz. 5, z glosą M. Szerera, OSPiKA 1974, nr 12, poz. 262,

3 Rozporządzenie Prezydenta Rzeczypospolitej z 11 lipca 1932 r. - Kodeks karny, Dz.U. nr 60, poz. 571, ze zm.

4 Ustawa z 19 kwietnia 1969 r. - Kodeks karny, Dz.U. nr 13, poz. 94, ze zm.

5 Ustawa z 23 kwietnia 1964 r. - Kodeks cywilny, t.j. Dz.U. 2017, poz. 459, ze zm. 
liczności legalizujące czyn, generalnie uznany za bezprawny ${ }^{6}$. Za ratio wszystkich kontratypów przyjmuje się wystąpienie kolizji dóbr, której nie można rozwiązać bez poświęcenia dobra mającego wartość społeczną przy założeniu, że uda się wykazać społeczną opłacalność poświęcenia określonego dobra dla ratowania innego 7 .

Zgodnie $\mathrm{z}$ art. $25 \$ 1$ i 2 k.k. obrona konieczna polega na odpieraniu bezpośredniego, bezprawnego zamachu (niektórzy autorzy dodają jeszcze wymóg, aby zamach był rzeczywisty ${ }^{8}$, skierowanego na jakiekolwiek dobro prawne, przy zachowaniu sposobu obrony współmiernego do niebezpieczeństwa zamachu. Faktycznym rezultatem obrony koniecznej jest poświęcenie dobra napastnika, które może zostać naruszone lub nawet zniweczone. Konsekwencją prawnomaterialną jest przyjęcie, że broniący się naruszył dobro prawne napastnika (realizując przy tym ustawowe znamiona typu czynu zabronionego), działając w sposób legalny. Innymi słowy, jego zachowanie nie było bezprawne, a zatem nie popełnił przestępstwa (zob. art. $25 \$ 1$ k.k., który rozpoczyna się od słów: Nie popetnia przestępstwa...). Konsekwencją formalnoprawną (procesową) będzie z kolei w takim wypadku: wyrok uniewinniający lub - na etapie postępowania przygotowawczego - umorzenie albo odmowa wszczęcia postępowania.

Sytuacją graniczącą z obroną konieczną jest działanie w warunkach przekroczenia granic obrony koniecznej. Od strony stanu faktycznego są to niejednokrotnie sytuacje bardzo zbliżone. Diametralnie odmienna jest jednak prawna ocena zachowania broniącego się z przekroczeniem granic obrony koniecznej, któremu przypisuje się działanie bezprawne, co może pociągać za sobą jego odpowiedzialność karną (gdy broniącemu się z przekroczeniem granic obrony koniecznej można dodatkowo przypisać winę oraz uznać, że jego zachowanie było społecznie szkodliwe w stopniu wyższym niż znikomy).

Przekroczenie granic obrony koniecznej może przybrać postać ekscesu intensywnego, kiedy zastosowano sposób obrony niewspółmierny do niebezpieczeństwa zamachu lub też ekscesu ekstensywnego, który zachodzi w dwojakiej sytuacji: obrony przedwczesnej - defensio antecedens, gdy zamach nie wszedł jeszcze w fazę bezpośredniości, lub też spóźnionej - defensio subsequens, gdy bezpośrednie zagrożenie zamachem już ustało". Jak wspomniano wyżej, konsekwencją przekroczenia granic obrony koniecznej jest bezprawność zachowania broniącego się, co może implikować jego odpowiedzialność karną. Sąd może jednak takiego sprawcę potraktować ulgowo, stosując - zgodnie z art. $25 \$ 2$ k.k. nadzwyczajne złagodzenie kary, a nawet odstąpienie od jej wymierzenia.

6 W. Wolter, Nauka o przestępstwie. Analiza prawnicza na podstawie części ogólnej kodeksu karnego z 1969 r., Warszawa 1973, s. 163.

7 A. Zoll, Okoliczności wyłączające bezprawność czynu. Zagadnienia ogólne, Warszawa 1982, s. 104.

8 M. Mozgawa, Komentarz aktualizowany do art. 25 Kodeksu karnego [w:] Kodeks karny. Komentarz aktualizowany, red. M. Mozgawa i in., 2017, LEX nr 534269.

9 M. Mozgawa, Komentarz aktualizowany do art. 25 Kodeksu karnego, op. cit. 
Z kolei na podstawie art. $25 \$ 3 \mathrm{k} . \mathrm{k}$. przekraczający granice obrony koniecznej (ustawodawca nie czyni tu rozróżnienia na eksces intensywny i ekstensywny) nie podlega karze, o ile działa pod wpływem strachu lub wzburzenia usprawiedliwionych okolicznościami zamachu. Przepis ten - z uwagi na liczne odwołania do niego, poczynione w treści petycji - wymaga szerszego omówienia.

Konsekwencja ekscesu wywołanego okolicznościami wskazanymi w art. 25 $\$ 3$ k.k. pierwotnie ujęta była mniej korzystnie dla występującego w obronie, jako obligatoryjne odstąpienie od wymierzenia kary. Ustawą z 5 listopada 2009 r. nowelizującą Kodeks karny (Dz.U. nr 206, poz. 1589, ze zm.), która weszła w życie z dniem 8 czerwca 2010 r., przepisowi temu - wychodząc naprzeciw postulatom doktryny i judykatury - nadano obecne brzmienie. Zmiana, polegająca na zastąpieniu „odstąpienia od wymierzenia kary” klauzulą „niepodlegania karze”, nie jest tylko zmianą redakcyjną, niesie ze sobą bardzo istotne konsekwencje czysto procesowe i prawnomaterialne.

$\mathrm{Z}$ procesowego punktu widzenia przypadki, w których ustawa stanowi, że sprawca nie podlega karze, prowadzą do prawnej niedopuszczalności postępowania karnego. Dlatego niepodleganie karze zaliczane jest do tzw. ujemnych przesłanek procesowych ${ }^{10}$. Stosownie do art. $17 \$ 1$ pkt 4 Kodeksu postępowania karnego ${ }^{11}$ zaistnienie ujemnej przesłanki procesowej przekłada się na obowiązek organu procesowego niewszczynania postępowania albo umorzenia postępowania już wszczętego. Ponieważ postępowanie karne nie może toczyć się bez ustalenia warunków jego dopuszczalności, organy prowadzące postępowanie zobligowane są na każdym etapie badać w pierwszej kolejności, czy postępowanie może się toczyć, a w razie stwierdzenia okoliczności wyłączającej postępowanie - podjąć w tym zakresie odpowiednią decyzję procesową ${ }^{12}$. Ustalenie niedopuszczalności postępowania $\mathrm{z}$ uwagi na przypadek niepodlegania karze, które miałoby miejsce jeszcze przed formalnym rozpoczęciem postępowania przygotowawczego (w drodze wydania postanowienia o wszczęciu śledztwa lub dochodzenia), prowadzić powinno do wydania postanowienia o odmowie jego wszczęcia. Późniejsze stwierdzenie zaistnienia tej okoliczności skutkuje natomiast: na etapie postępowania przygotowawczego - umorzeniem postępowania, zaś po rozpoczęciu przewodu sądowego - wydaniem wyroku umarzającego (art. $414 \$ 1$ k.p.k.).

$\mathrm{Na}$ gruncie procedury karnej niepodleganie karze z mocy ustawy (art. $17 \S 1$ pkt 4 k.p.k.) zaliczane jest także do tzw. materialnych przesłanek procesowych, podobnie jak niepopełnienie czynu, brak ustawowych znamion czynu zabronio-

10 M. Cieślak, O przesłankach procesowych w polskim postępowaniu karnym (podstawowe założenia i procesy metodologiczne), „Państwo i Prawo” 1969, z. 12, s. 953.

11 Ustawa z 6 czerwca 1997 r. - Kodeks postępowania karnego, t.j. Dz.U. 2016, poz. 1749, ze zm.; dalej: k.p.k.

12 Z. Gostyński, S. Zabłocki, Dział I. Przepisy wstępne [w:] J. Bratoszewski i in., Kodeks postępowania karnego. Komentarz, t. I, Warszawa 2003, s. 299. 
nego w zachowaniu sprawcy, wyłączenie przestępności czynu z mocy ustawy czy znikoma społeczna szkodliwość czynu (art. $17 \$ 1$ pkt 1, 2 i 3 k.p.k.). Wynika $\mathrm{z}$ tego, że znaczenie tej instytucji wykracza poza ramy prawa procesowego, gdzie postrzegana jest jako negatywny warunek dopuszczalności postępowania karnego. Niepodleganie karze stanowi jednocześnie negatywny warunek odpowiedzialności karnej w obszarze prawa materialnego ${ }^{13}$. Klauzulę bezkarności należy uznać za okoliczność uchylającą odpowiedzialność karną, gdyż prowadzi ona do zerwania normatywnego związku między przestępstwem a karą - związku, który jest konieczny dla pociągnięcia sprawcy do odpowiedzialności karnej ${ }^{14}$.

Sprawca nie ponosi odpowiedzialności karnej z powodu uchylenia przez ustawę karalności czynu, ale nie jego przestępności. Czyn sprawcy - ekscedenta nadal jest przestępstwem, jest bezprawny, zawiniony i w pewnym stopniu społecznie szkodliwy i tylko z uwagi na decyzję ustawodawcy pozostaje bezkarny. Wskazuje się przy tym, że w stwierdzeniu, iż sprawca nie podlega karze, zawarty jest mimo wszystko pewien element ujemnej oceny czynu, klauzula ta nie oznacza całkowitego jego usprawiedliwienia ${ }^{15}$.

Przepis art. $25 \$ 3 \mathrm{k} . \mathrm{k}$. spotkał się z niejednolitym odbiorem w doktrynie prawa karnego. Głosy aprobujące wskazują, że zmierza on do satysfakcjonującego społecznie rozwiązywania sytuacji konfliktowych, w których nastąpiło wprawdzie przekroczenie granic obrony koniecznej (a tym samym - popełnienie przestępstwa), ale sprawca ekscesu mimo to nie zasługuje na ukaranie ${ }^{16}$. Podkreśla się również, że w ten sposób uniknie się zbędnych procesów sądowych (a co za tym idzie - kosztów postępowania), jak również zaoszczędzi się ekscedentowi często niemiłych przeżyć związanych ze swoistą stygmatyzacją, wynikającą ze skierowania przeciwko niemu aktu oskarżenia i toczącego się procesu ${ }^{17}$. Głosy sceptyczne koncentrują się na różnorodnych aspektach tego uregulowania. I tak np. kwestionuje się zasadność posłużenia się formułą „nie podlega karze” w odniesieniu do sytuacji, o której mowa w art. $25 \$ 3$ k.k. Podnosi się, nie bez racji, że ocena zaistnienia przesłanek zastosowania tego przepisu - z uwagi na kwestie ustalania zawinienia - powinna być domeną sądu, a nie organów ścigania ${ }^{18}$. Nadto wskazuje się, że sytuacja, której dotyczy art. $25 \$ 3$ k.k., nie powinna być okolicznością wyłączającą karalność przestępstwa, lecz okolicznością wyłączają-

$13 \quad$ Ibidem, s. 298.

14 D. Gajdus, Czynny żal w polskim prawie karnym, Torun 1984, s. 181; K. Buchała, Prawo karne, Warszawa 1980, s. 608; A. Wąsek, Wspótsprawstwo w polskim prawie karnym, Warszawa 1977, s. 73.

15 L. Gardocki, Prawo karne, Warszawa 1998, s. 170.

16 J. Giezek, Komentarz do art. 25 Kodeksu karnego [w:] Kodeks karny. Część ogólna. Komentarz, red. J. Giezek, N. Kłączyńska, G. Łabuda, 2012, LEX nr 125523.

17 M. Mozgawa, Komentarz aktualizowany do art. 25 Kodeksu karnego, op. cit.

18 W. Wróbel, Opinia z 28 stycznia 2009 r. o zmianie ustawy - Kodeks karny i zmianie innych ustaw, druk sejmowy nr 1394/VI kad. 
cą przestępność czynu (z uwagi na brak winy) ${ }^{19}$. Inni autorzy podnoszą z kolei, że: nie przeżycia psychiczne ofiary zamachu, ale okoliczności zamachu sprawcy winny decydować o uznaniu przekroczenia granic obrony koniecznej za usprawiedliwione $^{20}$. Podnosi się także argument, że art. $25 \$ 3$ k.k.: zawiera swoista dyskryminację ludzi odpierających bezpośredni zamach przestępczy, którzy należą do kategorii osób bardzo odważnych i opanowanych. Dążac do realizacji skutecznej obrony, przekraczaja jednak jej granice ${ }^{21}$. Dlaczego: nie mieliby korzystać z obligatoryjnego odstapienia od wymierzenia kary? Dlatego, że nie bali się napastnika i bronili się bez wzburzenia? ${ }^{22}$.

Stawia się także pytanie: czy w jakiejkolwiek sytuacji możliwe jest stwierdzenie (udowodnienie), że przekroczenie granic obrony koniecznej nie zostało wywołane strachem lub wzburzeniem usprawiedliwionymi okolicznościami zamachu? Działającemu w obronie koniecznej także wówczas, gdy przekracza on jej granice, towarzysza emocje o wyraźnym zabarwieniu negatywnym, które $z$ natury rzeczy wywoływane sa przez sytuację zagrożenia. Można tutaj wymienić cała gamę uczuć, takich jak: strach, lęk, przerażenie, oburzenie, gniew, wściekłość itp. W zdecydowanej większości przypadków pojawiającym się uczuciem jest oczywiście strach. Własnymi siłami trzeba bowiem odeprzeć bezpośredni i bezprawny zamach zagrażajacy jakiemuś dobru chronionemu prawem (np. życiu, zdrowiu lub chociażby "tylko" mieniu), mając przy tym często do czynienia z profesjonalnie działającym napastnikiem. Gdyby jednak nawet uznać, że jest taka grupa przypadków, w których broniącemu się uczucie strachu nie towarzyszy (co, teoretycznie rzecz biorąc, jest oczywiście możliwe), to przecież zawsze będzie mógł on powołać się na wzburzenie (faktycznie występujące lub ex post jedynie deklarowane). Trudno zaś byłoby zaakceptować poglad, że okoliczności bezprawnego przecież zamachu $w$ jakiejkolwiek sytuacji mogłyby wzburzenia nie czynić zrozumiałym $i$ dającym się uzasadnić, zwłaszcza gdy mowa jedynie o jakości tego uczucia, nie zaś o jego natężeniu ${ }^{23}$.

\section{Ocena propozycji zgłoszonej w petycji}

Opiniowana propozycja zmian w zakresie przepisów Kodeksu karnego regulujących odpowiedzialność osoby przekraczającej granice obrony koniecznej dotyka niesłychanie istotnej społecznie kwestii sprawiedliwego potraktowania osoby, która, stając w obliczu bezprawnego zamachu, sama jest zmuszona

19 A. Zoll, Komentarz do art. 25 Kodeksu karnego [w:] Kodeks karny. Część ogólna, t. I, cz. I, Komentarz do art. 1-52, 2016, red. W. Wróbel, A. Zoll, LEX nr 510491, nb. 75. K. Daszkiewicz, Kodeks karny z 1997 roku. Uwagi krytyczne, Gdańsk 2001, s. 104 (rozdział Przekroczenie granic obrony koniecznej. Propozycja nowego ujęcia $\$ 3$ art. 25 k.k. O koniecznej obronie idei prawa. Błędne stosowanie przepisów o obronie koniecznej).

${ }^{21}$ Ibidem.

22 Ibidem.

23 J. Giezek, Komentarz do art. 25 Kodeksu karnego, op. cit., nb. 31. 
podjąć obronę lub decyduje się przyjść z pomocą innej osobie, i przy tej okazji wykracza poza granice przewidziane dla działań obronnych w przepisach prawa karnego. Sprawa jest tym bardziej delikatna, że prawnej oceny takiego zdarzenia dokona państwo w osobach umocowanych funkcjonariuszy wymiaru sprawiedliwości, działających ex post, bezpiecznie zasiadających w zaciszu gabinetów prokuratorskich czy sal sądowych - to samo państwo, którego zabrakło w krytycznym momencie zamachu. Waga zarysowanego tu zagadnienia nie powinna jednak przesłonić słabych stron przedłożonej propozycji nowelizacyjnej, o których poniżej.

Po pierwsze, należy odrzucić supozycję o nieoperatywnym charakterze kategorii „strachu lub wzburzenia usprawiedliwionych okolicznościami zamachu”, jako tej części normy zawartej w art. $25 \$ 3$ k.k., która - ze względu na nieokreśloność pojęć strachu i wzburzenia - nie daje organom wymiaru sprawiedliwości szansy na poprawne jej zastosowanie przy ocenie stanów faktycznych z przekroczenia granic obrony koniecznej. Jak pokazują wyniki badań $Ł$. Pohla i K. Burdziaka sądy stosują przepis art. $25 \$ 3$ k.k. w praktyce. Skutecznie poszukują w drodze wykładni odpowiedzi na pytanie, kiedy strach i wzburzenie usprawiedliwione są okolicznościami zamachu? Powołani wyżej autorzy wskazują, co warto podkreślić, że w zapadłych judykatach sądy nie tylko nie uchylały się od stosowania art. $25 \$ 3$ k.k., ale jednoznacznie wskazywały, że ocena działania sprawcy pod wpływem strachu lub wzburzenia jest wyłączną kompetencją sądu, a opinie biegłych (np. psychologa), choć odgrywają w tym zakresie niezwykle istotną rolę, nie mają decydującego znaczenia ${ }^{24}$.

Po drugie, nie można tracić z pola widzenia faktu, że raporty i opracowania dotyczące badań akt postępowań karnych z zakresu stosowania instytucji obrony koniecznej, jakie przywołano w treści uzasadnienia opiniowanej petycji, ograniczają swoje spektrum analityczne do postępowań zakończonych prawomocnym wyrokiem sądu. Jako autor jednego z przywołanych opracowań ${ }^{25}$ mam obowiązek zwrócić uwagę, że poza ich zakresem badawczym pozostały sprawy zakończone już na etapie postępowania przygotowawczego postanowieniem o umorzeniu postępowania lub odmowie jego wszczęcia z uwagi na okoliczność niepopełnienia przez sprawcę przestępstwa - działanie w granicach obrony koniecznej (art. $17 \$ 1$ pkt 2 k.p.k.) lub niepodlegania karze - przekroczenie granic obrony koniecznej w warunkach art. $25 \$ 3$ k.k. (art. $17 \$ 1$ pkt 4 k.p.k.). Ta kategoria spraw nie została dotychczas objęta badaniami - nie oznacza to, że w ogóle nie

24 Sygn. akt SA II AKa 29/17; SN IV sygn. akt KK 59/15 (zob. też: sygn. akt SO III K 82/15), cyt. za Ł. Pohl, K. Burdziak, Obraz i analiza wykładni sądowej przepisów Kodeksu karnego z 1997 r. o obronie koniecznej i przekroczeniu jej granic, Warszawa 2017 (raport w publikacji), s. 99-100.

25 P. Bachmat, Instytucja obrony koniecznej w praktyce prokuratorskiej i sądowej, „Prawo w Działaniu” 2008, nr 3, s. 39-117. 
występuje w praktyce organów wymiaru sprawiedliwości. Zważywszy na tę okoliczność, należy zdać sobie sprawę z faktu, iż przedstawiona w dotychczasowych raportach $\mathrm{z}$ badań generalnie niekorzystna ocena działań, zwłaszcza działań prokuratury, nie ma charakteru całościowego, a jedynie wycinkowy. Nie obejmuje bowiem tych przypadków (nie wiemy, czy są one liczne, czy nieliczne), w których prokuratura potraktowała działanie osoby odpierającej bezprawny, bezpośredni zamach na dobro prawne jako działanie legalne albo przynajmniej niezasługujące na ukaranie - to ostatnie mimo przekroczenia granic prawa do obrony.

Po trzecie, przechodząc do opiniowanej propozycji, została ona pomyślana jako kolejna (obok art. $25 \$ 3$ k.k.) prawna podstawa uwolnienia od kary sprawcy przekroczenia granic obrony koniecznej. Podstawą merytoryczną zagwarantowania ekscedentowi bezkarności byłaby sytuacja przekroczenia granic obrony koniecznej przy odpieraniu zamachu skierowanego przeciwko jednemu z dóbr prawnych wyegzemplifikowanych $\mathrm{w}$ treści proponowanego przepisu art. 25 $\S 3$ a k.k. Ich lista obejmuje: bezpieczeństwo powszechne, życie, zdrowie, wolność, wolność seksualną lub mienie, gdy zamach na mienie połączony jest z użyciem przemocy lub wdarciem się do cudzego domu, mieszkania, lokalu, pomieszczenia lub ogrodzonego terenu.

Przywołane rozwiązanie budzi następujące zastrzeżenia. Konstrukcja oparta na założeniu polegającym na premiowaniu ekscendenta tym, że niepodlega karze tylko z uwagi na fakt, że odpiera on zamach skierowany przeciwko określonemu dobru prawnemu, zdecydowanie zubaża perspektywę oceny jego zachowania, eliminując z niej nie tylko, jak chce tego autor petycji, sferę emocjonalną zachowania ekscendenta (strach i wzburzenie), ale również inne istotne elementy składające się na ocenę zdarzenia, jak np. rozkład sił między napastnikiem a broniącym się („osiłek” uzbrojony w niebezpieczne narzędzie versus starszy człowiek), konfiguracja interpersonalna (np. napastnicy versus pojedyncza osoba broniąca się, albo napastnik versus ojciec będący na spacerze z małymi dzieć$\mathrm{mi}$ ), konfiguracja sytuacyjna (zamach mający miejsce w nocy, na wyludnionej ulicy albo w nocy w mieszkaniu broniącego się), narzędzia i sposoby użyte przez napastnika i broniącego się czy zestawienie kolidujących w zdarzeniu kontratypowym dóbr prawnych, a także wiele innych elementów. Dobra regulacja tego zagadnienia powinna być też na tyle uniwersalna, aby okazała się przydatna do oceny zdarzeń, w których wektor oceny nie będzie już tak jednoznacznie skierowany na korzyć broniącego się, w sytuacji, w której to on ma zdecydowaną przewagę nad napastnikiem (siłową, liczbową, sytuacyjną itd.). Nowa regulacja powinna zawierać pewnego rodzaju wentyl bezpieczeństwa dla organów wymiaru sprawiedliwości, tj. powinna być w nią wpisana także możliwość zaniechania przez organy wymiar sprawiedliwości premiowania ekscendenta w sytuacji, w której wykorzystał swoją rażącą przewagę do obrony dobra stosunkowo niewielkiej wartości, przy poświęceniu dóbr o wartości najwyższej - jak życie czy zdrowie. Opiniowane rozwiązanie nie spełnia tego wymogu. 
W ocenie autora opinii zdecydowanie lepszym rozwiązaniem byłoby powiązanie niepodlegania karze ekscendenta z bardziej uniwersalną i pojemną zarazem formułą „usprawiedliwienia przekroczenia granic obrony koniecznej okolicznościami towarzyszącymi zamachowi”. Takie postulaty zostały nota bene zgłoszone w polskiej literaturze karnistycznej, jednak do tej pory nie zostały podjęte prace nad wdrożeniem tych propozycji w życie ${ }^{26}$.

Opiniowane uregulowanie zostało ujęte nazbyt szeroko, w sposób nie do końca przestający do przedstawionego uzasadnienia. Należy zwrócić uwagę, że propozycja nowego art. $25 \$ 3$ a k.k. została ujęta od strony redakcyjnej w taki sposób, że swoim zakresem obejmie nie tylko przypadki ekscesu intensywnego (sposób obrony niewspółmierny do niebezpieczeństwa zamachu), ale również sytuacje mieszczące się w ekscesie ekstensywnym (brak wskazanej w ustawie korelacji czasowej między zamachem a obroną, prowadzący do naruszenia zasady bezpośredniości zamachu, tzn. przypadki obrony przedwczesnej albo spóźnionej). Tymczasem cała warstwa argumentacyjna uzasadnienia dotyka kwestii ekscesu intensywnego. Autor nie podjął próby wykazania, czy proponowane rozwiązanie miałoby znaleźć zastosowanie także w przypadkach ekscesu ekstensywnego.

\section{Wnioski}

Zdaniem autora opinii przedłożona petycja nie wydaje się zasadna. Postulat ustanowienia art. $25 \$ 3$ a k.k., w brzmieniu zaproponowanym przez autora petycji, nie zasługuje na aprobatę. Niepodleganie karze ekscendenta tylko z uwagi na fakt, że ten występuje w obronie określonych dóbr prawnych, dokonane w oderwaniu od innych istotnych elementów zdarzenia kontratypowego, spłyca ocenę jego zachowania i może prowadzić do obligatoryjnego uwalniania od kary w przypadkach społecznie nieakceptowanych.

\section{Bibliografia}

Bachmat P., Instytucja obrony koniecznej w praktyce prokuratorskiej i sadowej, „Prawo w Działaniu" 2008, nr 3.

Buchała K., Prawo karne, Warszawa 1980.

Cieślak M., O przesłankach procesowych $w$ polskim postępowaniu karnym (podstawowe założenia i procesy metodologiczne), „Państwo i Prawo” 1969, z. 12.

Daszkiewicz K., Kodeks karny z 1997 roku. Uwagi krytyczne, Gdańsk 2001

Gajdus D., Czynny żal w polskim prawie karnym, Toruń 1984.

26 K. Daszkiewicz, Kodeks karny z 1997 roku, op. cit., s. 104; Ł. Pohl, K. Burdziak, Obraz i analiza wykładni sq̨dowej, op. cit., s. 98. 
Gardocki L., Prawo karne, Warszawa 1998.

Giezek J., Komentarz do art. 25 Kodeksu karnego [w:] Kodeks karny. Część ogólna. Komentarz, red. J. Giezek, N. Kłączyńska, G. Łabuda, 2012, LEX nr 125523.

Gostyński Z., Zabłocki S., Dział I. Przepisy wstępne [w:] J. Bratoszewski i in., Kodeks postępowania karnego. Komentarz, t. I, Warszawa 2003.

Mozgawa M., Komentarz aktualizowany do art. 25 Kodeksu karnego [w:] Kodeks karny. Komentarz aktualizowany, red. M. Mozgawa i in., 2017, LEX nr 534269.

Wąsek A., Wspótsprawstwo w polskim prawie karnym, Warszawa 1977.

Wolter W., Nauka o przestępstwie. Analiza prawnicza na podstawie części ogólnej kodeksu karnego z 1969 r., Warszawa 1973.

Zoll A., Komentarz do art. 25 Kodeksu karnego [w:] Kodeks karny. Część ogólna, t. I, część I, Komentarz do art. 1-52, 2016, red. W. Wróbel, A. Zoll, LEX nr 510491.

Zoll A., Okoliczności wyłączające bezprawność czynu. Zagadnienia ogólne, Warszawa 1982. 